Рекомендована д. фрармац. наук, проф. В. В. Трохимчуком

УДК 658.3:0057

DOI 10.11603/2312-0967.2017.4.8347

\title{
ОБҐРУНТУВАННЯ МЕТОДІВ ДІАГНОСТИКИ ОРГАНІЗАЦІЙНОЇ КУЛЬТУРИ ФАРМАЦЕВТИЧНИХ ОРГАНІЗАЦІЙ
}

\author{
() І. В. Кубарєва, Н. В. Чмихало, Л. А. Карпенко \\ Національний фрармацевтичний університет, Харків \\ socpharm@nuph.edu.ua
}

\begin{abstract}
Мета роботи. Обґрунтування вибору методу діагностики організаційної культури фрармацевтичних організацій 3 подальшим його опрацюванням в аптечних організаціях м. Харкова.

Матеріали і методи. Аналіз основних праць вітчизняних і зарубіжних фрахівців у галузі менеджменту за допомогою загальнонаукових методів, системного і комплексного аналізу; соціологічних досліджень.

Результати й обговорення. В статті проведено аналіз існуючих методик діагностики організаційної культури організації (ОКО), серед яких для подальшого опрацювання обрано методику DOCS (Denison Organizational Culture Survey) - модель Даніеля Денісона, що спрямована на виявлення впливу організаційної культури на економічну еорективність організації. У рамках моделі на базі аптечних закладів м. Харкова було оцінено 12 індикаторів ОкО та розраховані значення їх індексів.

Висновки. Обґрунтовано доцільність використання при аналізі організаційної культури фрармацевтичних організацій моделі Деніеля Денісона (DOCS), яка проста у використанні, має інформаційну надійність про стан організаційної культури та дозволяє проводити порівнянність результатів при вивченні декількох організацій.
\end{abstract}

Ключові слова: фрармацевтичні організації; організаційна культура; діагностика організаційної культури.

Вступ. Тематичний словник-довідник з соціології визначає термін «організаційна культура» як «...специфрічне поєднання цінностей, відносин, норм, звичок, традицій, орорм поведінки і ритуалів, які існують в організації» [12]. У межах теорії менеджменту організаційна культура є синонімом терміну «корпоративна культура» та позиціонується як потужний стратегічний інструмент, що дає змогу орієнтувати всі підрозділи організації і окремих осіб на спільні цілі; мобілізувати ініціативу співробітників; забезпечувати відданість організації; полегшувати процес комунікації. Враховуючи соціальну спрямованість організацій фрармацевтичного профрілю, їх організаційна культура повинна відповідати існуючій у суспільстві системі ідеалів, цінностей і норм та формувати власний потенціал внутрішньоорганізаційних ціннісних установок. Для використання корпоративної культури в інтересах своєї організації необхідно, в першу чергу, діагностувати ії̈ поточний стан $[12,16]$.

Оцінити можливість реалізації стратегії компанії (форми, підприємства) і вирішити, змінювати цілі та завдання або вибудовувати іншу корпоративну культуру, що відповідає новій стратегії, допоможе діагностика корпоративної культури.

Окремі положення організаційної культури в історичному ракурсі розглядали визнані авторитети у сорері управління: Ф. Тейлор, Г. Форд, А. Вебер, М. Портер, С. Паркінсон, А. Маслоу. Вплив організаційної культури на ефективність діяльності підпри- ємств представлено в публікаціях зарубіжних вчених: І. Ансофрфа, М. Армстронга, Г. Даулінга, М. Томпсона, Р. Харісона та іншіх. Суттєвий вклад у розвиток теорії і практики організаційної культури фрармацевтичної організації внесли вчені: Л. В. Галій, А. А. Котвіцька, 3. М. Мнушко, А. С. Немченко, О. В. Посилкіна, В. М. Толочко та ін. $[8,13,14,17,18]$.

Незважаючи на високий рівень та різноманітність зарубіжних та вітчизняних досліджень методів діагностики організаційної культури, динамічність соціально-економічних процесів у країні, а також наявність національних особливостей зумовлює актуальність даного напрямку досліджень для фрармацевтичних організацій.

3 огляду на вищеозначене метою роботи є обґрунтування вибору методу діагностики організаційної культури фрармацевтичних організацій 3 подальшим його опрацюванням в аптечних організаціях м. Харкова. Для реалізації означеної мети було поставлено такі завдання:

- проведення теоретичного обґрунтування основних методик діагностики організаційної культури організації;

- здійснення аналізу організаційної культури аптечних організацій за методикою DOCS (Denison Organizational Culture Survey - модель Даніеля Денісона).

Матеріали і методи. Теоретичну і методологічну основу дослідження склали основні праці вітчизня-

ISSN 2312-0967. Pharmaceutical review. 2017. № 4 
Фармацевтичний менеджмент, маркетинг та логістика Pharmaceutical management, marketing and logistics

них і зарубіжних фрахівців у галузі організаційної культури. У процесі дослідження використані такі методи: загальнонаукові (узагальнення, контент-аналіз, логічний аналіз), системний підхід і комплексний аналіз; соціологічні (анкетування), методика побудови організаційної моделі Д. Денісона.

Результати й обговорення. У фрармацевтичній енциклопедії організаційна культура визначається як «...набір найбільш важливих припущень, які приймаються членами організації та відображаються в заявлених нею цінностях, які є орієнтирами для працівників у їхній поведінці та діях» [5].

До основних складових організаційної культури відносять $[9,10]$ :

- зовнішні прояви культури, з якими одразу стикаються клієнти та партнери (фірмовий стиль, манеру спілкування, лозунги, прийнятий дрес-код, оздоблення офрісних приміщень, офріційні церемонії, корпоративні заходи тощо);

- внутрішня частина організаційної культури, а саме: правила, які визначають етику та деонтологію фармацевтичного працівника, ставлення до споживачів лікарських засобів та медичних виробів, партнерів, держави, суспільства, самої організації. Основними документами, які регулюють ці правила, $є$ Корпоративні кодекси фрармацевтичних підприємств як найвищі стандарти індивідуальної поведінки, що створюють взаємну довіру, Етичний Кодекс фрармацевтичних працівників України та посадові інструкції;

- глибинний рівень культури, який виступає як мотиваційна складова для відповідальних за фрормування організаційної культури [6, 7, 20, 21].

У теорії менеджменту, економіки та соціології описано три основні методики діагностики організаційної культури організації (ОКО): холічеська (передбачає використання спостереження за організацією 3 метою виявлення характеристик її культури), метафорична (основана на вивченні внутрішньої документації - статуту, документів, що регламентують взаємовідносини і обмін інформацією всередині організації, протоколів зборів, засідань, нарад та ін.) і кількісна (передбачає проведення опитувань і співбесід для оцінки культури організації) $[11,22]$. Враховуючи те, що кількісна стратегія діагностики організаційної культури дозволяє отримати дані, які мають кількісні характеристики, а сама методика містить соціальноетичний компонент та відповідає вимогам доступності проведення соціологічних досліджень, вона $€$, на нашу думку, найбільш адаптивною до аналізу організацій фармацевтичного профрілю. Серед кількісних методів найбільш розроблені, описані і часто використовуються такі методики [15, 19], як:

- OCI (Organizational culture inventory) Р. Кука і Дж. Лаффрерті, методика за якою $є$ можливість провести оцінку організаційною культури за дванадцятьма стилями: людинолюбним; дружнім; схвальним; ввічливим; залежним; таким, що ухиляється; проти- лежним; силовим; конкуруючим; вимогливим; успішним; самоактуалізаційним [15];

- DOCS (Denison Organizational Culture Survey) модель Даніеля Денісона, спрямована на виявлення впливу організаційної культури на економічну ефективність організації, вона оцінює компанію за двома напрямами: внутрішнє та/або зовнішнє середовище і стабільність як швидкість реакції організації на зміни фракторів прямої та непрямої дії означених середовищ. Безпосередньо складові організаційної культури аналізуються за такими складовими [4]:

- місія організації, яка включає: стратегічний напрямок, намір та цілі і завдання як розуміння і поділ стратегії і завдань співробітниками; бачення як задоволеність співробітників напрямком розвитку організації;

- адаптивність, яка виражається у здатності до змін, увазі до клієнтів та навчанні організації;

- залученість, яка $€$ показником рівня відповідальності співробітників за спільну справу шляхом надання повноважень, орієнтації на роботу в команді та можливості розвитку співробітників;

- узгодженість, яка визначає цінності організації та проводить самоідентифрікацію співробітників із компанією, визначає їх здатність до консенсусу та сприйняття співробітниками різних підрозділів загальних цінностей і норм.

Слід особливо підкреслити, що поєднання місії ma узгодженності в основному впливає на такі фрінансові показники, як прибутковість активів / Return on Assets (ROA), прибутковість інвестицій / Return on Investment (ROI) та прибутковість продажів / Return on Sales (ROS), взаємодія місії та адаптивності впливає на доходи, зростання продажів і частку ринку. Поєднання складових узгодженості та залученості є фрактором якості, задоволеності працівників і віддачею від інвестицій (ROI), а поєднання залученості і адаптивності впливає на розвиток товарної та інноваційної політик. Сьогодні означену модель застосовують більш ніж 1200 організацій у всьому світі, в тому числі в Україні [3].

- OCAI (Organizational Culture Assessment Instrument) К. Камерона і Р. Куїнна - єдина методика, яка дає загальний профріль культури організації та $є$ найбільш доступним методом, з точки зору трудомісткості. Інструмент ОСАІ дозволяє ідентифрікувати існуючу культуру організації і визначити, якою вона повинна бути переважно з точки зору співробітників організації. OCAI має фрорму опитувальника, питання якого характеризують: організацію в цілому; загальний стиль лідерства організації; управління працівниками; сполучну сутність організації; стратегічні цілі та критерії успіху організації [19].

Враховуючи той фракт, що фармацевтичний сектор прямо впливає на здоров'я нації та $€$ соціальним інститутом, який забезпечує доступність фрармацевтичної допомоги, він знаходиться під пильною ува-

ISSN 2312-0967. Фармацевтичний часопис. 2017. № 4 
гою як з боку держави, так й суспільства в цілому Вищенаведене вимагає від підприємств фрармацевтичного сектора формування позитивної організаційної культури та періодичного ії̈ моніторингу.

Аналіз досвіду групи фрармацевтичних компаній «Маркет Універсал», яка $€$ лідером орармацевтичного ринку Західного регіону України та отримала Європейський сертисрікат бізнес компетентності (European Business Competence Licence), EBC*L, дозволив нам деталізувати, що саме завдяки позитивізму організаційної культури компанія створила унікальні продукти, а саме: сучасну комп'ютерну програму аптечного і управлінського обліку, систему управління якістю за стандартом ISO 9001, програму лояльності для постійних клієнтів «Подяка за довіру», просвітницький телевізійний проект для населення «Запитайте в аптеці», перший корпоративний «Соціальний звіт», проекти «Інтерактивний музей «Таємна аптека» та Інтернет-магазин товарів для здоров'я і краси «DSK@». В цілому в Україні серед фрармацевтичних компаній, які фрункціонують на українському ринку на принципах корпоративізму, можна виділити «Корпорацію Артеріум», ПАТ «Фармак», «GlaxoSmithKline», «Bayer» та інші [1].

Необхідно підкреслити, що всі вищеозначені стратегії можуть мати застосування при аналізі організаційної культури фрармацевтичних організацій. Але враховуючи те, що модель Деніеля Денісона (DOCS) має достатню точність, наочність і об'єктивність результатів дослідження, проста у використанні та наданні надійної й достовірної інорормації про стан організаційної культури і дозволяє проводити порівнянність результатів при вивченні декількох організацій, для подальших досліджень було обрано саме цю модель. В якості об'єктів дослідження нами обрано мережеві аптеки м. Харкова, загальна чисельність яких склала 25 аптек, тому в експерименті вони отримали нумерацію від № 1 до № 25. Для репрезентативності даних було обрано аптеки за зіставними да- ними: чисельністю фрармацевтичного штату, обсягів роботи (навантаження на одного працівника), пішохідною прохідністю, кількістю споживачів за добу та вартістю середнього чеку. Як респонденти виступили керівники вищого рівня управління.

Для вимірювання ОКО була складена спеціальна анкета, в якій зазначені 4 основні характеристики, кожна з яких структурована за індикаторами - термінами, які описують специфрічні аспекти культури в рамках, зазначених анкетою Даніеля Денісона. Враховуючи те, що в своїй моделі Даніель Денісон розглядав такі риси ОКО, як місія, узгодженість, участь та адаптивність, ми для характеристики «Місія» використовували такі індикатори, які надають чіткий і зрозумілий напрям у стратегічному розвитку організації та мають конкретні цілі й завдання щодо його реалізації. Характеристику ОКО «Узгодженість» (послідовність) ми розглядали у контексті індикаторів, які становлять основу сильної культури, а саме: координація, згода та ключові цінності працівників фрармацевтичних організацій. Характеристику «Залученість» ми формували індикаторами, які показують відчуття власності та відповідальності працівників, а характеристику «Адаптивність» - індикаторами, що підвищують організаційну спроможність для виживання, росту та розвитку [3].

За результатами даних, отриманих з анкет, розраховані значення індексів основних фракторів ОКО, які можна представляти у відсотках (максимальне значення індексу 5 балів, або 100 \%) (табл. 1).

На рисунку 1 представлено порівняльний аналіз основних характеристик ОКО та їх індикаторів у реальному та бажаному станах.

Отримані значення показують, що робітники аптек досить високо оцінюють організаційну культуру власної організації. Однак значення такої характеристики ОКО, як «Залученість», яка має низьке значення (67\%), є результатам отриманих низьких рейтинго-

Таблиця 1. Значення основних характеристик та індикаторів ОКО, \%

\begin{tabular}{|l|c|}
\hline Характеристики та індикатори ОКО & Значення індикаторів ОКО, \% \\
\hline Місія організації: & 86 \\
стратегічна спрямованість; & 84 \\
цілі і завдання; & 75 \\
бачення $\quad$ Узгоженість: & $\mathbf{8 1}$ \\
\hline координація та інтеграція; & 77 \\
згода; & 80 \\
ключові цінності & 85 \\
\hline Залученість: & 67 \\
повноваження; & 58 \\
орієнтація на роботу в команді; & 75 \\
розвиток здібностей & 69 \\
\hline Адаптивність: & $\mathbf{8 3}$ \\
здатність до змін; & 72 \\
орієнтація на клієнта; & 100 \\
здатність організації до навчання & 78 \\
\hline
\end{tabular}

ISSN 2312-0967. Pharmaceutical review. 2017. № 4 
Фармацевтичний менеджмент, маркетинг та логістика

Pharmaceutical management, marketing and logistics

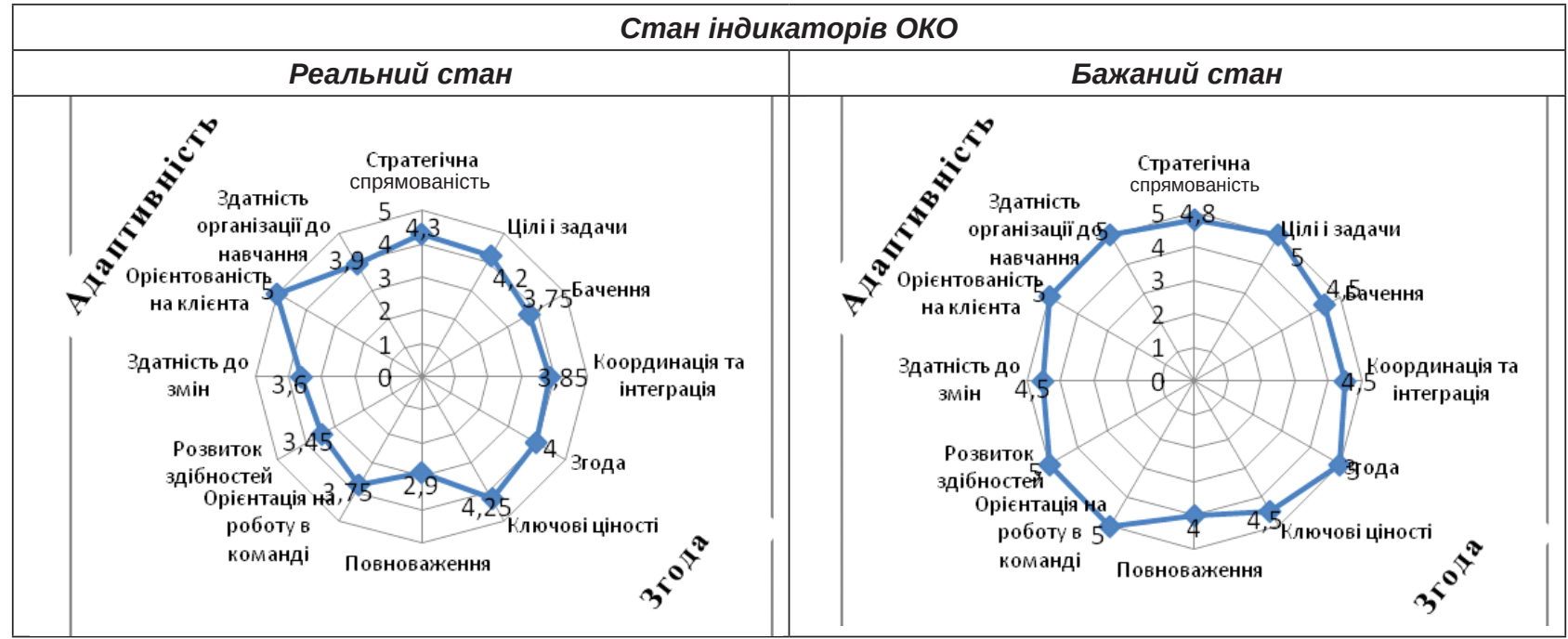

Рис. 1. Графрічне (бальне) представлення індикаторів ОКО (реальний та бажаний стан).

вих показників її індикаторів «Повноваження» (58 \%) та «Розвиток здібностей» (69 \%). Слід підкреслити, що повноваження як опосередкованість владних відносин між керівним і підлеглим учасниками цих відносин не сприймаються останнім як важлива складова ОКО і оцінена тільки на 2,9 бала, індикатори орієнтація на роботу в команді та розвиток здібностей оцінені респондентами на 3,75 та 3,45 бала відповідно (з максимальних - 5). На наш погляд, такі дані $€$ результатом недостатності інорормації та свободи вибору (дії) відносно як повноважень робітників, так і розвитку їх здібностей, що потребує від керівництва перегляду стратегії організаційної культури за даним напрямом. Водночас, такі значення індикаторів ОКО знижують есективність діяльності організації в цілому. Означена робоча ситуація потребує від керівника (не залежно від рівня управління) розширення та конкретизації повноважень підлеглих як шляхом де- легування власних повноважень, так й за рахунок фрормування команд (робочих груп) з вирішення проблемних питань ринкової ситуації, що надасть працівникам можливість подальшого розвитку та розкриття власних здібностей.

В той же час найбільш високі значення отримали індикатори, що характеризують місію компанії (cmpaтегічна спрямованість - 86 \% (4,3 бала), цілі і завдання - $84 \%(4,2)$. Бачення місії, її практичну реалізацію підтримали 75 \% респондентів (3,75 бала). Маємо констатувати, що значення індексу місії і узгодженості від 3 до 4 зазвичай вказує на високу віддачу від активів і продажів, а також на ефективність операційної діяльності організації. У даному дослідженні означені результати отримали 4,1 та 4,0 балів, відповідно, що є позитивним результатом.

Наочне зображення поточного профрілю ОКО аптечної організації представлено на рисунку 2.

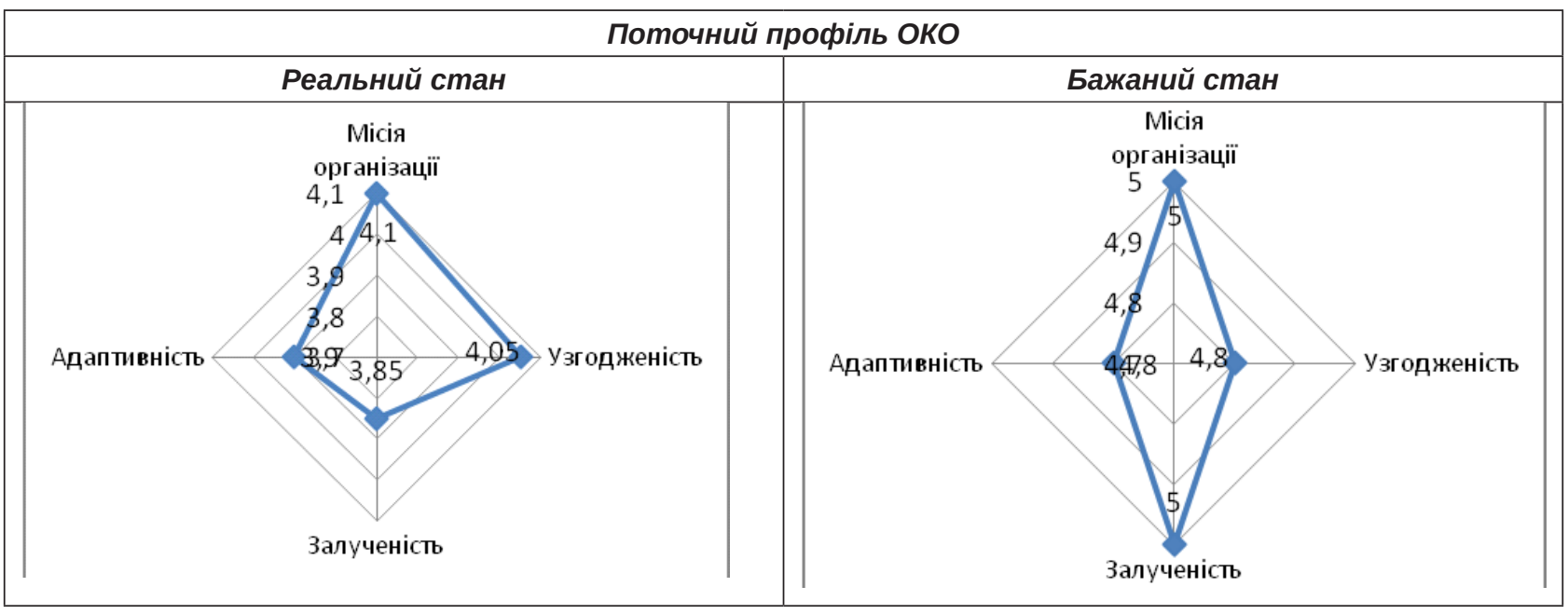

Рис. 2. Поточний профріль ОКО фрармацевтичної організації.

ISSN 2312-0967. Фармацевтичний часопис. 2017. № 4 
Фармацевтичний менеджмент, маркетинг та логістика Pharmaceutical management, marketing and logistics

Узагальнюючи вищенаведене, вважаємо за доцільне проведення на постійній основі досліджень із визначення стану організаційної культури на підприємствах і організаціях фрармацевтичного сектора галузі охорони здоров'я з метою моніторингу впливу організаційної культури на ринкову сталість організації.

Висновки. 1. Проведено описовий аналіз основних методик діагностики організаційної культури організації, визначено їх сутність та деталізовано, що кількісна методика за змістом та відповідністю вимогам доступності проведення соціологічних досліджень $€$ найбільш адаптивною до аналізу організацій фрармацевтичного профрілю.

2. Визначено, що кількісна стратегія діагностики організаційної культури представлена такими методиками, як ОCl (Organizational culture inventory) Р. Кука і Дж. Лафрферті, DOCS (Denison Organizational Culture Survey) модель Даніеля Денісона, OCAI (Organizational Culture Assessment Instrument) K. Kaмерона і Р. Куїнна.

3. Обґрунтовано доцільність використання при аналізі організаційної культури фрармацевтичних ор- ганізацій моделі Деніеля Денісона (DOCS), яка проста у використанні, має інформаційну надійність про стан організаційної культури та дозволяє проводити порівнянність результатів при вивченні декількох організацій.

4. Опрацювання моделі Деніеля Денісона (DOCS) здійснено на фрармацевтичних організаціях м. Харкова та отримано такі результати:

- практично всі респонденти досить високо оцінюють організаційну культуру власної організації, окрім характеристики «Залученість», яку вони оцінили тільки у 3,35 бала з 5 максимальних. Це значення $€$ прямим результатом низької оцінки такого її індикатора, як «Повноваження» - 2,9 бала, що потребує від керівництва організації комплексного перегляду стратегії організаційної культури за даним напрямом;

- найбільші значення отримали такі характеристики організаційної культури, як «Місія» та «Узгодженість» - 4,2 та 4,0 бала відповідно, що свідчить про високу віддачу від активів і продажів, а також про ефрективність діяльності та ринкову сталість організації.

\title{
ОБОСНОВАНИЕ МЕТОДОВ ДИАГНОСТИКИ ОРГАНИЗАЦИОННОЙ КУЛЬТУРЫ ФАРМАЦЕВТИЧЕСКИХ ОРГАНИЗАЦИЙ
}

\author{
И. В. Кубарева, Н. В. Чмыхало, Л. А. Карпенко \\ Национальный фрармацевтический университет, Харьков \\ socpharm@nuph.edu.ua
}

Цель работы. Обоснование выбора метода диагностики организационной культуры фрармацевтических организаций с дальнейшим его использованием для анализа в аптечных организациях г. Харькова.

Материалы и методы. Анализ работ отечественных и зарубежных специалистов в области менеджмента с помощью общенаучных методов, системного и комплексного анализа; социологических исследований.

Результаты и обсуждение. В статье проведен анализ существующих методик диагностики организационной культуры организации (ОКО), среди которых для дальнейшей обработки выбрана методика DOCS (Denison Organizational Culture Survey) - модель Даниэля Денисона, направленная на выявление влияния организационной культуры на экономическую эфрфективность организации. В рамках модели на базе аптечных организаций г. Харькова было оценено 12 индикаторов ОКО и рассчитаны значения их индексов.

Выводы. Обоснована целесообразность использования при анализе организационной культуры фрармацевтических организаций модели Даниэля Денисона (DOCS), которая проста в использовании, имеет информационную надежность относительно состояния организационной культуры и позволяет проводить сопоставимость результатов при изучении нескольких организаций.

Ключевые слова: фрармацевтические организации; организационная культура; диагностика организационной культуры.

ISSN 2312-0967. Pharmaceutical review. 2017. № 4 
Фармацевтичний менеджмент, маркетинг та логістика

Pharmaceutical management, marketing and logistics

\title{
THE SUBSTANTIATION OF DIAGNOSTIC METHODS OF ORGANIZATIONAL CULTURE OF PHARMACEUTICAL ORGANIZATIONS
}

\author{
I. V. Kubarieva, N. V. Chmykhalo, L. A. Karpenko \\ National University of Pharmacy, Kharkiv \\ socpharm@nuph.edu.ua
}

The aim of the work. Substantiating the choice of a method for diagnosing of the organizational culture of pharmaceutical organizations with its further use for analysis in pharmacy organizations in Kharkiv.

Materials and Methods. Analysis of works of domestic and foreign specialists in the management field with the help of general scientific methods, system and complex analysis; sociological research.

Results and Discussion. The article analyzes the existing organizational culture (OC) diagnosis methods, among which, for further research, Denison model or DOCS (Denison Organizational Culture Survey) method aimed at identifying the influence of organizational culture on the economic efficiency of the organization was chosen. Within the framework of the model on the pharmacy organizations basis in Kharkov, 12 indicators of OC were evaluated and the values of their indices were calculated.

Conclusions. The expediency of using the Denison model (DOCS) for analyzing the organizational culture of pharmaceutical organizations, which is easy to use, has information reliability concerning the state of OC and allows comparability of results in the study of several organizations was substantiated.

Key words: pharmaceutical organizations; organizational culture; organizational culture diagnosis.

\section{Список літератури}

1. Аналіз досвіду групи фрармацевтичних компаній «Маркет Універсал 10 років під брендом «D.S.»: відродження і розвиток традицій львівської фрармації // Аптека. - № 24 (1045) 27 июня 2016 г. http://www.apteka.ua/ article/376267

2. Братішко Ю. С. Роль корпоративної культури у фрормуванні системи соціальної відповідальності фрармацевтичних підприємств / Ю. С. Братішко // Молодий вчений. - 2014. - № 12 (15). - С. 232-238.

3. Верезомська І. Г. Діагностика організаційної культури підприємства готельно-ресторанного бізнесу за методом Даніеля Денісона // Науковий вісник Полтавського університету економіки і торгівлі. - 2013. - № 5 (61). С.71-77.

4. Галимова Н. А. Исследование организационной культуры организации среднего образования методом ОСАІ / Н. А. Галимова // Молодой ученый. - 2016. - № 2. - C. 444-451.

5. Кайдалова А. В. Корпоративна (організаційна) культуpa [Електронний ресурс]. - Режим доступу: http://www. pharmencyclopedia.com.ua/article/6060/korporativnaorganizacijna-kultura

6. Кодекс корпоративного управління ПАТ «Гедеон Ріхтер YA» https://www.stockworld.com.ua/.../nreg_report543297145d..

7. Кодекс корпоративного управління «Фармак» https:// www.farmak.ua/.../kodeks_korporativnogo_oupravli..

8. Котвіцька А. А. Наукове обґрунтування соціальноетичної моделі поведінки працівників аптек у конорліктних ситуаціях: метод. рек. / А. А. Котвіцька, Н. В. Тетерич - Х., 2009. - 26 с.

9. Лісрінцев Д. С. Методичні основи оцінки впливу корпоративної культури на діяльність організації [Електронний ресурс] // Електронне наукове фрахове видання
«Ефрективна економіка». - Режим доступу: http://www. economy.nayka.com.ua/?op=1\&z=635

10. Ліфінцев Д. С. Корпоративна культура як інструмент формування іміджу організації / Д. С. Ліфрінцев // Стратегія економічного розвитку України. - 2009. - Вип. 24-25. - C. 190-193.

11. Марсель ван Ассен. Ключевые модели менеджмента : монография Марсель ван Ассен. - М. : БИНОМ, Лаборатория знаний, 2012. - 323 с.

12. Менеджмент: Понятійно-термінологічний словник [За ред. Г.В. Щокіна та ін.]. - К. : МАУП, 2007. - 744 с.

13. Мнушко 3. М. Сучасні підходи до адаптивного управління фрармацевтичними організаціями / 3. М. Мнушко, І. В. Бондарева // Управління, економіка та забезпечення якості в срармації, 2008. - Т.1, № 2. - С. 37-42.

14. Немченко А. С. Обґрунтування організаційної структури управління системою оцінок нових технологій в охороні здоров'я та фрармації в Україні : метод. рек. / А. С. Немченко, К. Л. Косяченко. - Харків, 2011. - 20 с.

15. Слинкова О. К. Сравнительный анализ методик оценки предпринимательской, управленческой и организационной культуры / О. К. Слинкова, П. В. Харитонова // Вестник НГУ. Серия: Социально-экономические науки. - 2012. - Т. 12. - Вып. 1. - С. 47-54.

16. Тематичний словник-довідник з соціології / За ред. В. В. Кохана; укл. А. Александровська, Є. Буга, Ю. Ткачук та ін. - Чернівці : Чернівецький нац. ун-т, 2009. - 112 с.

17. Толочко В. М. Управління персоналом фрармацевтичних організацій на основі компетенцій : монографрія / В. М. Толочко, Л. В. Галій // - Х. : Ависта-ВЛТ, 2010. $-180 \mathrm{c}$.

18. Управління трудовим потенціалом фрармацевтичних підприємств в умовах менеджменту якості : монограсрія / О. В. Посилкіна, О. В. Доровський, Ю. С. Братішко,

ISSN 2312-0967. Фармацевтичний часопис. 2017. № 4 
М. І. Сидоренко; за ред. профр. О.В.Посилкіної. - Х. НФаУ, 2010. - 416 c.

19. Чижикова Е. С. Исследование типа корпоративной культуры с помощью метода OCAI К. Камерона и Р. Куинна / Е. С. Чижикова // Современные проблемы науки и образования. - 2016. - № 3 ; URL: https://www. science-education.ru/ru/article/view?id=24782

20. Етичний кодекс фрармацевтичних працівників України [Фармацевтичний етичний кодекс України] Електронний pecypc: http://fp.com.ua/articles/etichniy-kodeks-farmatsevtichnih-pratsivnikiv-ukrayini-farmatsevtichniy-etichniykodeks-ukrayini/

21. Етичний Кодекс Санофрі. Електронний ресурс: www. sanofi.ua/l/ua/uk/download.jsp?file=34509959...

22. Cameron K. S. Diagnosing and changing organizational culture: based on the competing values framework / K. S. Cameron, R. E. Quinn. - San Francisco, CA : JosseyBass, 2006. - 242 p.

\section{References}

1. Analysis of the experience of pharmaceutical companies group "Market Universal 10 years under the brand" D.S. ": the revival and development of traditions of Lviv pharmacy. Available from: http://www.apteka.ua/article/376267

2. Bratishko YuS. [The role of corporate culture in shaping the system of social responsibility of pharmaceutical companies]. Molodyi vchenyi. 2016;12: 232-38. Ukrainian.

3. Verezomska IG. [Diagnosis of organizational culture of the hotel and restaurant business enterprise by the method of Daniel Denison]. Naukovyi visnyk Poltavskoho universytetu ekonomiky i torhivli. 2013;5: 71-7. Ukrainian.

4. Galimova NA. [Research of organizational culture of the secondary education organization by the OCAl method] Molodoy uchenyy. 2016;2: 444-51. Russian.

5. Kaydalova AV. [Corporate (organizational) culture]. Available from: http://www.pharmencyclopedia.com.ua/article/6060/korporativna-organizacijna-kultura.

6. Corporate Governance Code of PAT «Gedeon Richter UA». Available from: https://www.stockworld.com.ua/.../ nreg report-543297145d

7. Pharmac Corporation Code of Corporate Governance. Available from: https://www.farmak.ua/.../kodeks_korporativnogo_oupravli

8. Kotvitska AA., Teterych NV. Scientific substantiation of social and ethical model of behavior of pharmacy workers in conflict situations. [Наукове обґрунтування соціально-етичної моделі поведінки працівників аптек у конфрліктних ситуаціях: метод. рек.] Kharkiv; 2009. Ukrainian.

9. Lifintsev DS. Methodical bases of estimation of influence of corporate culture on organization's activity. Electronic scientific special edition" Effective economy". Available from: http://www.economy.nayka.com.ua/?op=1\&z=635 10. Lifintsev DS. [Corporate culture as an instrument for shaping the organization's image]. Stratehiia ekonomichnoho rozvytku Ukrainy. 2009;24-5: 190-3. Ukrainian.

11. Marsel van Assen. Key management models [Ключевые модели менеджмента: монографрия]. Moscow; 2012. Russian.

12. Management: Concept and terminology dictionary. [Менеджмент: Понятійно-термінологічний словник]. Kyiv: Interregional Academy of Personnel Management; 2007. Ukrainian.

13. Mnushko ZM, Bondareva IV. [Modern approaches to adaptive management by pharmaceutical organizations]. Upravlinnia, ekonomika ta zabezpechennia yakosti v farmatsii. 2008;1(2): 37-42. Ukrainian.

14. Nemchenko AS, Kosyachenko KL. Grounding of the organizational management structure of system of assessments of new technologies in health-care and pharmacy in Ukraine. [Обґрунтування організаційної структури управління системою оцінок нових технологій в охороні здоров'я та фрармації в Україні: метод. рек.] Kharkiv; 2011. Ukrainian.

15. Slinkova OK., Haritonova PV. [Comparative analysis of methods for assessing entrepreneurial, managerial and organizational culture]. Vestnik NGU. Seriya: Sotsialno-ekonomicheskie nauki. 2012;12(1): 47-54. Russian.

16. Aleksandrovska A, Buha Ye, Tkachuk Yu. Thematic dictionary-reference book on sociology. [Тематичний словник-довідник з соціології] Chernivtsi: Chernivtsi National University; 2009. Ukrainian.

17. Tolochko VM, Haliy LV. Personnel management of pharmaceutical organizations based on competences [Управління персоналом фрармацевтичних організацій на основі компетенцій: моногр.] Kharkiv; 2010. Ukrainian. 18. Posylkina OV, Dorovskyy OV, Bratishko YuS, Sydorenko MI. Management of labor potential of pharmaceutical enterprises in terms of quality management [Управління трудовим потенціалом фармацевтичних підприємств в умовах менеджменту якості: монограсрія]. Kharkiv: National University of Pharmacy; 2010. Ukrainian.

19. Chyzhykova ES. [A study of the corporate culture type using the K. Cameron and R. Quinn OCAI method]. Sovremennye problemy nauki i obrazovaniya. 2016; 3. Available from: https://www.science-education.ru/ru/article/ view?id=24782. Russian.

20. Ethical Code of Pharmaceutical Workers of Ukraine. Available from: http://fp.com.ua/articles/etichniy-kodeksfarmatsevtichnih-pratsivnikiv-ukrayini-farmatsevtichniyetichniy-kodeks-ukrayini/

21. The Sanofi Ethics Code. Available from: www.sanofi. ua/l/ua/uk/download.jsp?file=34509959.

22. Cameron KS, Quinn, R.E. Diagnosing and changing organizational culture: based on the competing values framework. San Francisco, CA: Jossey-Bass; 2006. 